\title{
Unravelling the life cycle of 'Polystomella crispa': the roles of Lister, Jepps and Myers
}

\author{
JOHN W. MURRAY \\ National Oceanography Centre Southampton, University of Southampton Waterfront Campus, European Way, Southampton SO14 3ZH, UK \\ *Corresponding author (e-mail: jwm1@noc.soton.ac.uk)
}

\begin{abstract}
The meticulous observations of Lister, Jepps and Myers involved the culturing of material, monitoring the behaviour of live individuals over periods of days and weeks and at different times of the year, and decalcifying tests in order to stain and examine the protoplasmic contents with the best available microscopes. They all based their studies at the Laboratory of the Marine Biological Association in Plymouth and Myers and Jepps overlapped in the early 1940s although they chose to work separately. Through their combined efforts they determined that the life cycle of Elphidium crispum (Linné) (formerly called Polystomella crispa) involves an alternation of generations, sexual and asexual, over a two-year period. This has remained the 'classic' life cycle of benthic foraminifera, although subsequent studies, including those of Myers, have revealed other patterns. Lister also established that test dimorphism is not related to sex but to the asexual and sexual phases of reproduction. J. Micropalaeontol. 31(2): 121-129, July 2012.
\end{abstract}

KEYWORDS: foraminifera, dimorphism, life cycle, history of research

\section{INTRODUCTION}

The life cycle of fewer than 30 species of foraminifera were known by 1999 (Goldstein, 1999) and no further studies have been published since that date. This paper is concerned with recording the earliest investigations. Considering the limited equipment available to them and the small size of the juvenile gamonts and agamonts, the early biologists made considerable progress in unravelling the life cycle of foraminifera. Key workers were the British protozoologists Joseph Jackson Lister (18571927) and Margaret Wolfe Jepps (1892-1977). The German Fritz Schaudinn (1871-1906), a contemporary of Lister, and the Frenchman Jean Le Calvez (1908-54), a contemporary of Jepps, also contributed to these studies. The English workers studied Polystomella crispa (now known as Elphidium crispum (Linné)). The American zoologist Earl Hamlet Myers (1898-1975) also studied the life history of Polystomella crispa at the same time as Jepps. Apart from his biological approach, he also made contributions to the rate of accumulation of foraminiferal tests in the sedimentary record, a subject of considerable interest to geologists. The Laboratory of the Marine Biological Association, Plymouth, played a key role in these studies as many of the observations were made there. Lister visited in the summers of 1894, 1904 and 1905, and Jepps 1938-40.

\section{JOSEPH JACKSON LISTER (1857-1927)}

Joseph Jackson Lister (Fig. 1) came from a family of scientists. His grandfather (Joseph Jackson Lister, 1786-1869) was a founder member of the Royal Microscopical Society. He was a wine merchant with an interest in microscopes and invented the use of achromatic pairs of lenses to overcome spherical aberration. His son, Joseph Lister (1827-1912, father of J.J. Lister of foraminiferal fame) was an eminent surgeon who introduced many new techniques to health care (Vickerman \& Sleigh, 2000).

In the nineteenth century the younger Joseph Jackson Lister was the major British zoologist investigating the biology of benthic foraminifera. He had trained in natural sciences and medicine. Because of poor health he was advised to take long cruises and to give up medicine. On these cruises he developed an interest in foraminifera and this led to a lectureship in Zoology at Cambridge (Vickerman \& Sleigh, 2000). His two key contributions were to establish the alternation of generations as the basic reproductive cycle of Polystomella crispa (now Elphidium crispum) and to explain dimorphism of the test (Lister, 1895; 1906). He laid the foundations built upon by later workers, such as Jepps and Myers. Unlike the latter, he also had a broad overview of the fossil record and used his zoological studies to interpret morphological features seen in fossil material (Lister, 1903; 1905).

When Lister commenced his research very little was known of the reproductive processes in foraminifera. However, there were a number of observations of benthic foraminifera in culture that produced young individuals. The first was that of Gervais (1847) who observed a triloculine parent (i.e. having a test with chambers onehalf coil in length, added successively in three planes $120^{\circ}$ apart; Loeblich \& Tappan, 1987) giving rise to $\sim 100$ juveniles. There were numerous, somewhat contradictory records of the number of nuclei with no understanding of their significance (see Lister, 1895, for a review; the referees for this paper were Ray Lankester and W.F.R Weldon, Royal Society, RR.12.178 and 179).

Lister was meticulous in making observations on carefully stained material (Lister, 1895; 1903). His laboratory notebooks are housed in the Heron-Allen Library of the Natural History Museum (volumes 1-5, 1892-1909). Lister's microscope slides are numbered sequentially and the notes are accompanied by beautifully drawn and water colour images (see Fig. 2). Volumes 1 and 2 relate to the studies of the foraminiferal life cycle and the remaining three volumes form the basis for the chapter in the Lankester Treatise (Lister, 1903). Lister was able to demonstrate that the life cycle consists of an alternation of generations, sexual and asexual. The megalospheric form (having a large proloculus and a single nucleus) is the product of asexual reproduction, and the microspheric form (having a small proloculus and several nuclei) is the result of sexual reproduction involving the fusion of two flagellated gametes produced during gametogenesis by the megalospheric form. He also recognized that there may be repeated megalospheric phases interspersed with occasional sexual phases, just as in other protozoa. He pointed out that in unilocular 


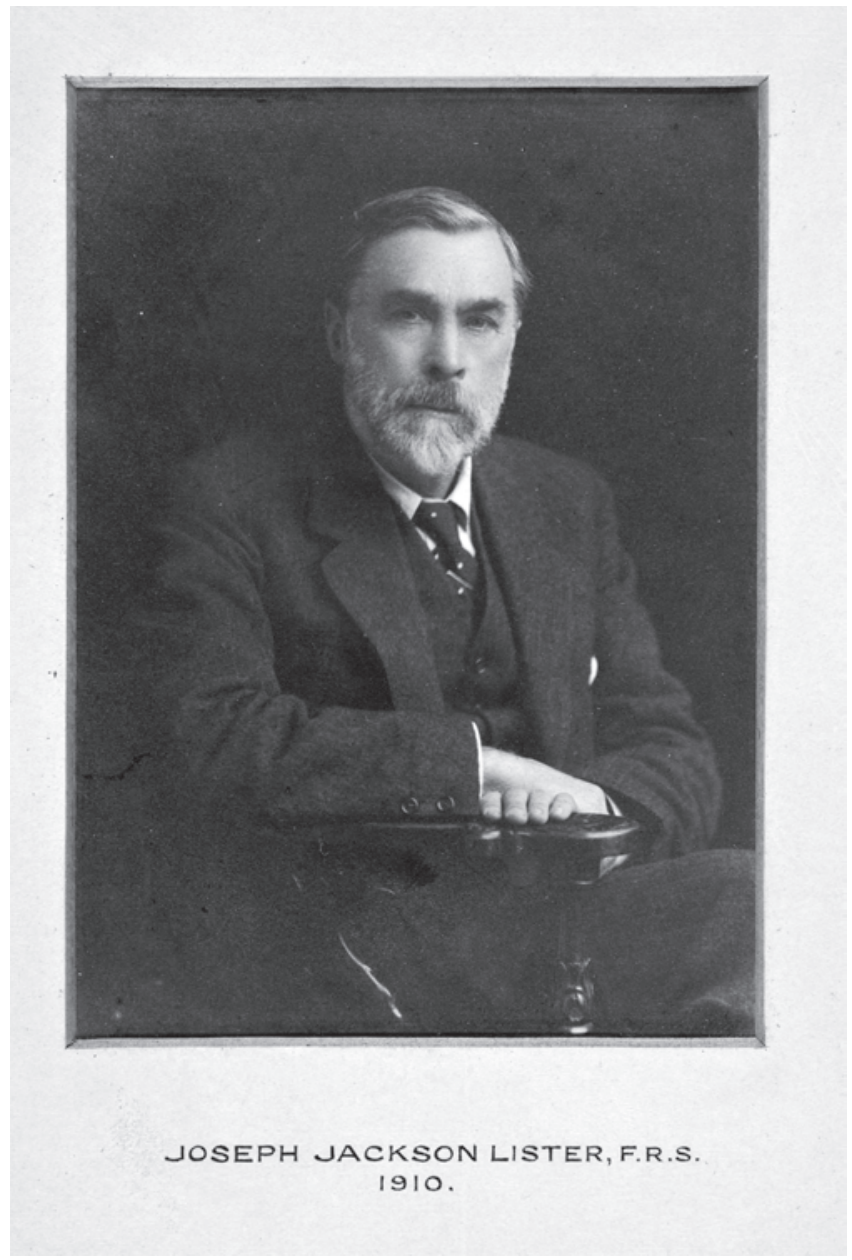

Fig. 1. Joseph Jackson Lister (courtesy of the Natural History Museum, London).

tests the size of the initial chamber is not preserved as the single chamber increases in size with growth. Lister also demonstrated that the position of the nucleus changes as the individual grows. Apart from studying Polystomella crispa, Lister also collected live 'Orbitolites complanatus' Lamarck, Calcarina hispida Brady and Cycloclypeus carpenteri Brady from Tonga and made observations on their nuclei. He commented on the observation that planktonic forms have uniformly small initial chambers 'a condition I suspect to depend on their peculiar mode of life' (Lister, 1906, pp. 591-2). It is now recognized that planktonic forms reproduce solely sexually (Hemleben et al., 1989).

Dimorphism was already recognized in benthic foraminifera, especially in larger forms such as nummulites (see review of literature by Lister, 1895). It was known that megalospheric forms commonly had smaller tests than the microspheric forms. However, the cause remained unexplained. Lister showed that these dimorphs represent the different phases of the alternation of generations. This is different from the sexual dimorphism of metazoans. He extended his study into Eocene nummulites from England, making sections to examine the proloculus (Lister, 1905).

After his 1895 paper, Lister continued his research at Plymouth, sometimes working throughout the night to observe the reproductive processes of Polystomella crispa. He contributed a section on Protozoa to a textbook (Lister, 1903) which remained the most comprehensive review of the biology of foraminifera until that of Jepps (1956). He published short notes on talks (Lister, 1906; 1907) but he did not publish his detailed results on his post-1895 work. In 1928, after Lister's death, his final paper was read by invitation at the Linnean Society. This was illustrated with his 'remarkable series of Lantern-slides' (Heron-Allen, 1930). These are photographs printed on glass for projection on to a screen with a projector illuminated with an arc lamp (originally known as a 'magic lantern' - hence 'lanternslides'). His laboratory notebooks with original drawings in water colour were put on display for the first time. Due to what HeronAllen (1930) considers to have been poor advice from an anonymous referee, the paper was rejected and was not published by the Linnean Society. Nevertheless, Heron-Allen amended the final paper with material from the notebooks and it was published by the Smithsonian Institution. Lister showed that over a period of around 12 hours a microspheric parent gave rise to a brood of megalospheric young. The stages in this process are beautifully illustrated by a series of 20 photomicrographs made by Lister (plates 1-7 in Heron-Allen, 1930), shown in public lectures (Lister, 1903; 1907) (see Fig. 3a-d for examples).

\section{MARGARET WOLFE JEPPS (1892-1977)}

It has not been possible to obtain a photograph of Jepps. The illustration in Vickermann and Sleigh (2000, fig. 27, attributed to the Royal Society) may not be correct. She was not an FRS and the Royal Society does not posses a photograph of her so the source of the published illustration is unknown and it may not be of Jepps. Jepps was born in London, graduated in zoology from Cambridge in 1915 and gained a DSc at Glasgow in 1938. She had a varied career and was one of the first women academics (Vickerman \& Sleigh, 2000). From 1915 to 1926 she was assistant to the Professor of Zoology at the University of Glasgow, with interruptions from 1916-19, doing war service as a protozoologist with the Medical Research Council. From 1921-22 she worked on amoebic dysentery at the Institute of Medical Research in Kuala Lumpur. Then from 1926-52 she was Lecturer in Protozoology at the University of Glasgow and research associate 1952-53. During this period she held a Leverhulme Research Fellowship (1938-42) at the Laboratory in Plymouth and in 1949 she received a Fulbright travel grant to visit the USA. Her fields of interest ranged from parasitic amoebae to foraminifera and freshwater sponges ('Jepps manuscript 89', Natural History Museum library, London). Following retirement in 1952 she returned to Cambridge to continue research. She was greatly admired for her teaching and the NHM library has a valentine card embellished with water colour paintings of protozoans prepared by students and sent to her to acknowledge this (illustrated in Vickerman \& Sleigh, 2000, fig. 29).

Jepps published two significant works on foraminifera: the paper on Polystomella crispa (Jepps, 1942) and her practical textbook on Sarcodine Protozoa (Jepps, 1956) written in retirement and published with funding from the Carnegie Trust. Apart from these, she published notes on Gromia, and particularly the two-layer structure of the wall, the nucleus and division (Jepps, 1926), and a letter on the nucleus of Cycloclypeus (Jepps, 1953). She collaborated with Earland to describe an individual of E. crispum which had become 


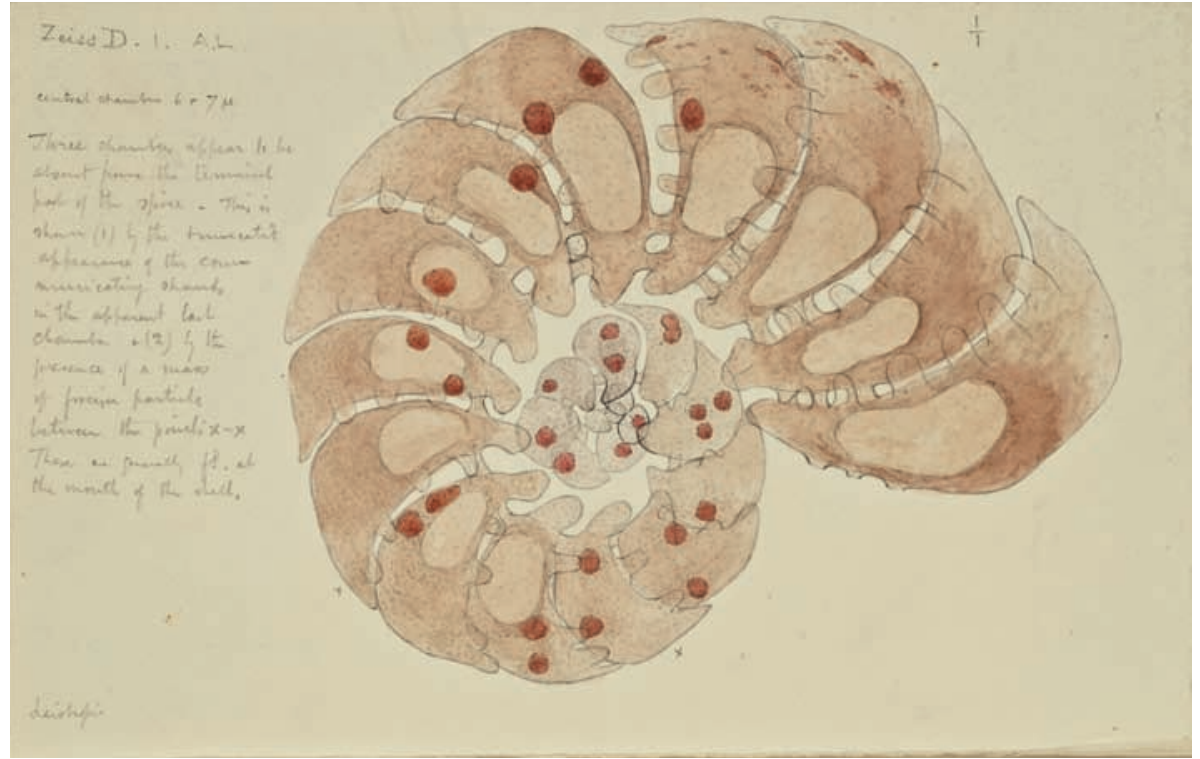

(a)

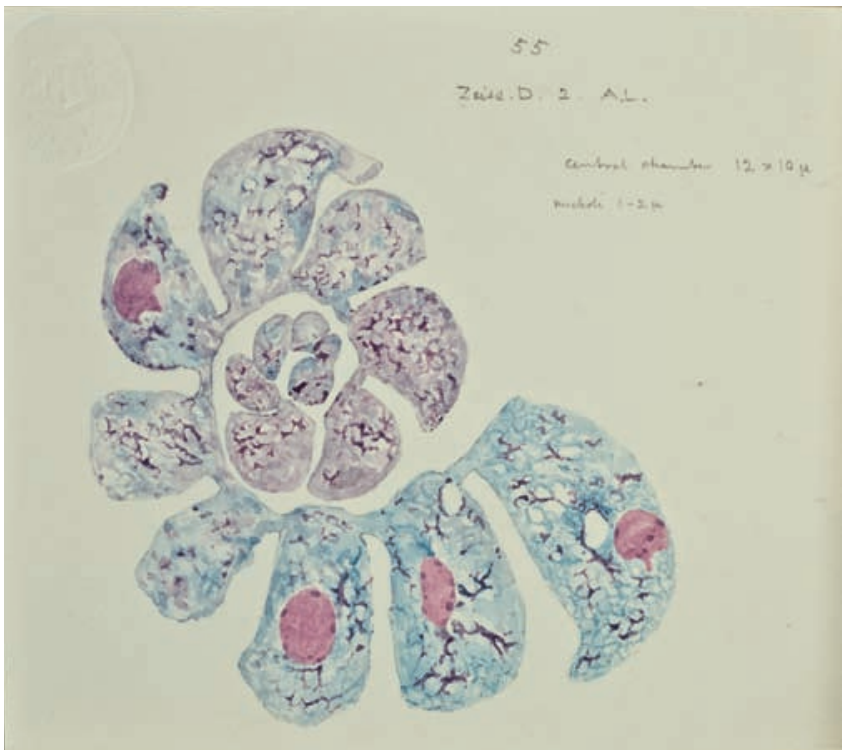

(b)

Fig. 2. (a) Watercolour painting of sarcode of Polystomella crispa showing 28 nuclei (dark red) and pencilled notes (Lister, Lab. Notebook vol. 1, slide 1). (b) Watercolour painting of sarcode of microspheric (microcaryate of Lister) Polystomella crispa showing nuclei (dark red) and pencilled notes (Lister, Lab. Notebook vol. 1, slide 55). Lister notes that the nuclei are the same size throughout the test.

partially uncoiled. They could not offer an explanation of the cause and lamented 'Unfortunately biological research (not having any commercial value) still limps feebly behind shell systematics in Foraminifera' (Earland \& Jepps, 1943, p. 46).

In the introduction to her classic paper on Polystomella crispa, Jepps (1942, p. 607) wrote

There must be a vast number of biologists who, like myself, were taught as students a life history of Polystomella based on the careful observations of J.J. Lister $(1895,1906)$ with additions that he accepted from the work of Schaudinn ...
To others beside myself it must have come as somewhat of a shock to realize later on the incompleteness of the these observations; and most particularly the slender basis on which rests the special contribution of Schaudinn.

In the academic year 1938-39, Jepps was granted leave of absence from Glasgow to spend a year at the Laboratory of the Marine Biological Association in Plymouth, funded by a Leverhulme Fellowship. Thus, she followed in the footsteps of J.J. Lister and obtained her material from the same area of Plymouth Sound (White Patch) as did Earl Hamlet Myers. In a 


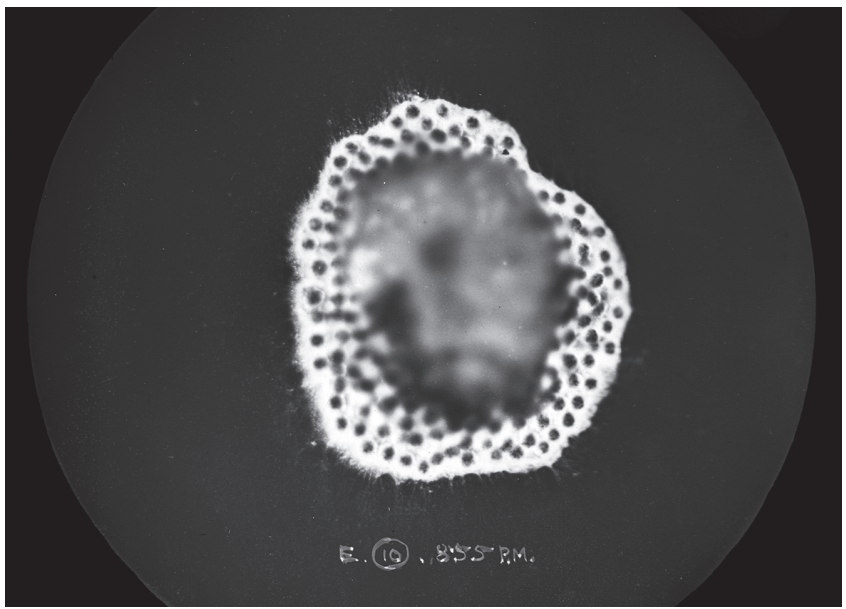

(a)

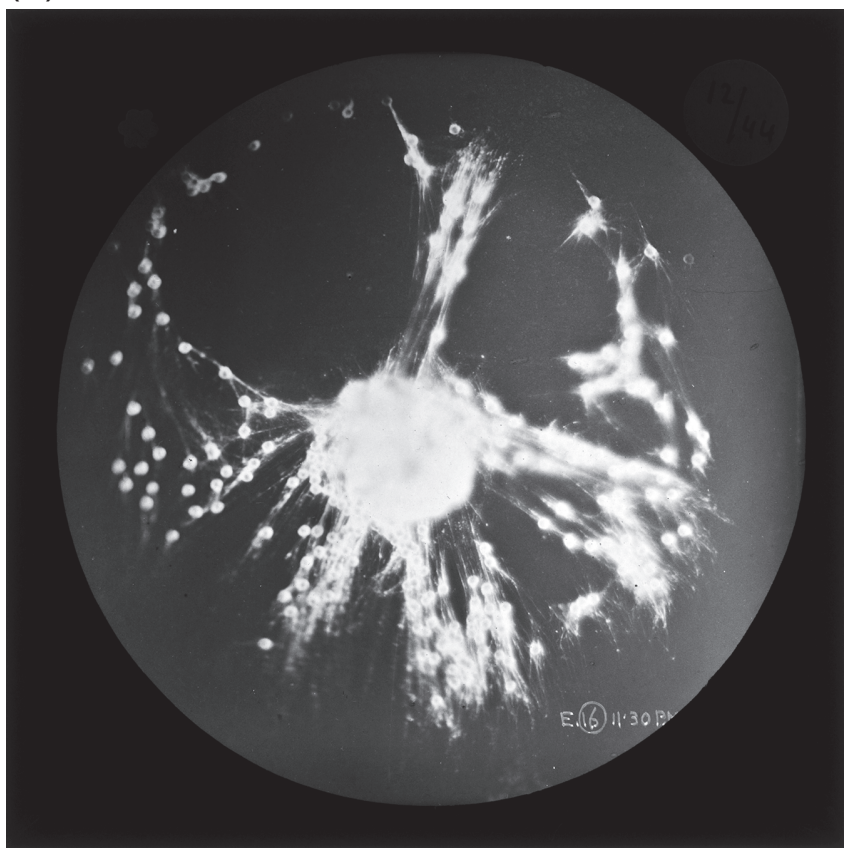

(c)

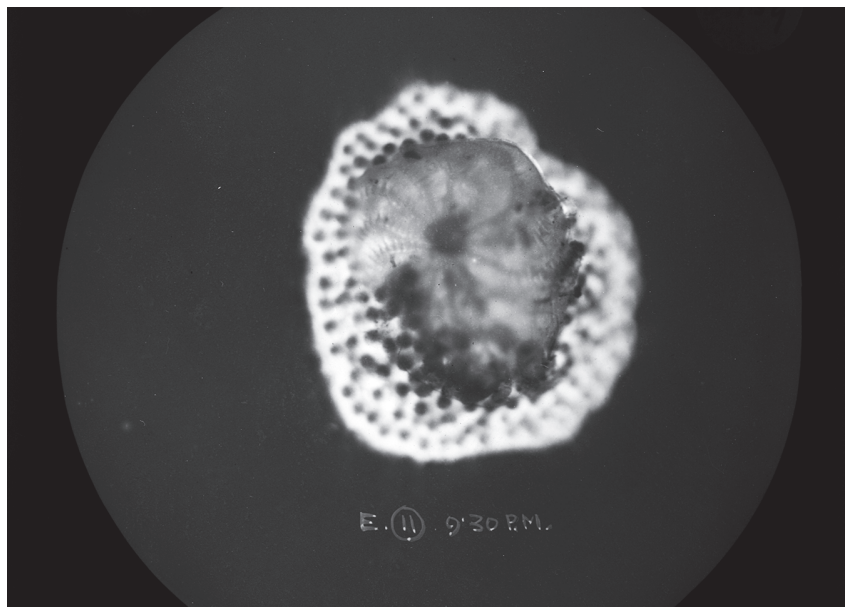

(b)

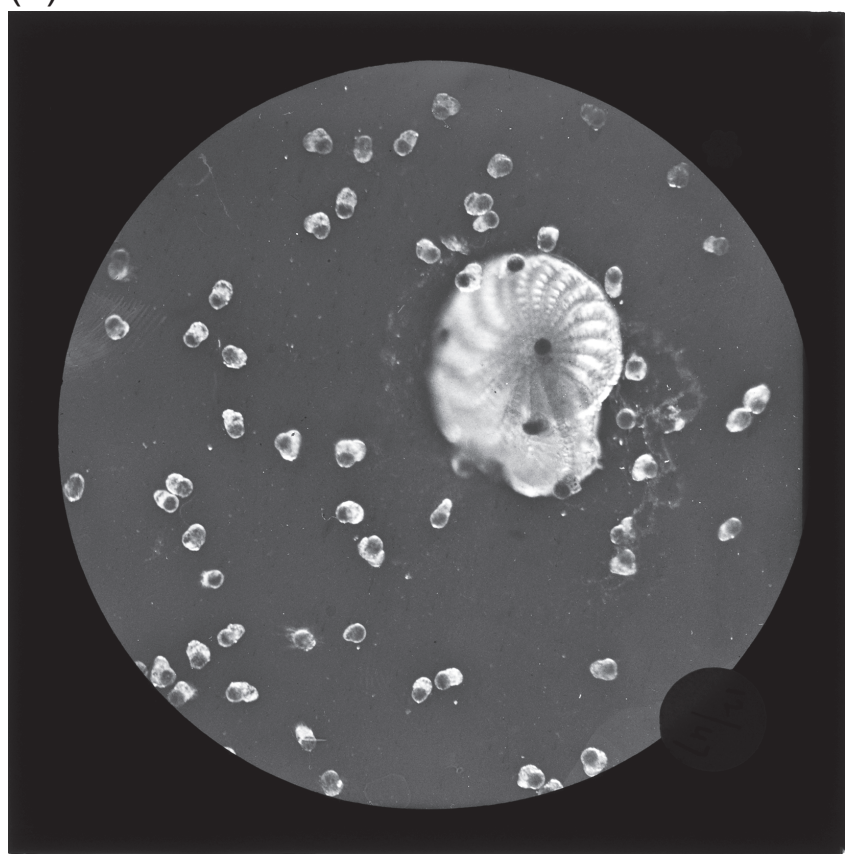

(d)

Fig. 3. (a-d). Lantern slides (for projection) prepared by Lister showing reproduction in Polystomella crispa. (a) and (b) were taken during a single reproductive event on 22 May 1895 and are at different levels of focus: (a) 12/38; (b) 12/39; (c) 12/44; (d) 12/47. They show the parent test surrounded by a halo of protoplasm with megalospheric juveniles; (c) and (d) show the dispersal of juveniles.

footnote (Jepps, 1942, p. 614) she records meeting Myers and his wife (also a zoologist) in Plymouth in the summer of 1938. They showed her their 'fine preparations' and their special paraffin embedding bath. Jepps notes of the Myers 'They decided to work on Polystomella while they were at Plymouth, and we agreed to continue our separate researches which lay along such different lines, quite independently, although for a time under the same roof'. Later in the text (Jepps, 1942, p. 634), she wrote

It will be interesting to compare my account of the annual cycle, based on general observation and cultures, with that of Earl H. Myers derived from his statistical investigation of very large numbers of specimens during the same year in Plymouth.
It seems remarkable that they did not correspond with one another or compare notes.

In Part 1 of the Jepps (1942) paper various topics were discussed, including methods of fixation of material, culturing diatoms as food, cleaning freshly caught foraminiferal specimens to be used in cultures, the hatching of turbellarian worms from egg cases attached to the foraminiferal test, and xanthosomes described as 'coloured excretory granules'. She also described the formation of feeding cysts, and the presence of foraminiferal plugs and xanthosomes in the canal system from which they are discharged at the fossettes or terminal apertures. She also determined that the colour of the food influences the colour of the protoplasm within the test, and that starvation leads to loss of colour over a period of 
3-4 weeks although may be restored if food is again available. She observed that placing Polystomella (and other foraminifera) in fresh water causes the protoplasm to swell and ooze out of the fossettes and terminal apertures. Observations of feeding were undertaken by isolating a small individual on a microscope slide and setting up an irrigation system to replenish the sea water. Over the course of a week, a small individual added two new chambers. Protoplasmic activity was speeded up when the irrigation system was operating. Locomotion was as much as $1 \mathrm{~mm}$ in $10-15$ minutes. It was influenced by currents during irrigation and they did not seek out food except through random movement. Nor did they remain in a good feeding area once they ceased feeding. Among the observations made on the pseudopodia she observed that not only do they catch the food but also digest it; no food is ever found inside the test. She considered the minute diatoms that Williamson (1851) recorded inside the test of Polystomella were really loose foraminiferal plugs (the bouchons of Le Calvez, 1938) from the retral processes.

Part 2 of Jepps (1942) concerns the biennial cycle and various observations on reproduction and the distinction of microspheric and megalosperic tests. Like Lister, Jepps regarded Schaudinn's (1903) account of the life cycle as partly erroneous. Many of her observations confirm those of Lister (1895; see also Heron-Allen, 1930; Le Calvez, 1938) but some are new. She established that microspheric forms reproduce by schizogony (repeated asexual reproduction) in the spring and summer and that there is an increase in the number of nuclei in the parent from autumn to spring. The maximum number of nuclei was 116 in an individual collected in March. She reported on two broods of megalospheric forms born in Petri dish cultures. The first, born on 7 February comprised 150 young. Two features are of interest. The parent test did not lose all its protoplasm and it slowly increased the amount from $4 \frac{1}{2}$ chambers to almost all exposed chambers by 8 April. However, by 28 May it was apparently dead. Of the juveniles, by 30 April most had grown to a diameter of $1 \mathrm{~mm}$. The second brood was born between 17 and 23 February and again the parent test did not lose all its protoplasm. By 7 April all the chambers were filled and on 23 August Jepps fixed the specimen confirming that all chambers were filled but also that there were $\sim 12$ small nuclei 'usually characteristic of a megalospheric form'. By 2 September the young were $>1 \mathrm{~mm}$ in diameter. The rate of chamber formation averaged one per two days for a period of three months. Individuals collected from the sea in June grew a new chamber every day for ten days. She also noted that individuals bred in culture often developed thickened tests for reasons unknown. She concluded that if the life cycle is of two generations its duration would normally be two years.

Part 3 of Jepps (1942) concerns the production of flagellated gametes (she termed the process 'sporulation' and the gametes 'flagellates'). The parent turns dazzling white and from $\sim 2$ a.m. to daybreak the gametes are released as a cloud (see Fig. 4C). Jepps wrote that she agreed with the observations made by Lister but not with some of his interpretations, perhaps due to the difficulties of fixing and examining the material. No fusion was observed even during prolonged examination under the microscope. She estimated that a single parent might produce $\sim 500000$ gametes. She was not surprised at the lack of success due to the small chance of observing fusion. However, Schaudinn (1903) observed fusion and the production of a microspheric test which survived until it had formed five chambers (see Fig. 4K2).
It is worth recording the immense amount of work it takes to keep foraminifera in culture, provide them with food, ensure that the medium is refreshed and oxygenated, and the many hours spent making microscopic observations as the author knows from personal experience (Murray, 1963). One can, therefore, only admire the tenacity and dedication of observers such as Lister and Jepps.

In the textbook on Sarcodine Protozoa (Jepps, 1956) she commences by pointing out that the earliest studies of Protozoa (e.g. Ehrenberg, 1838) took for granted that they were 'complete little animals' and that they therefore had the same set of organs as metazoans. The book reviews the current state of knowledge of the Sarcodina, of which Foraminifera are just one order.

Jepps writes from a biological perspective with particular attention to the life cycle, especially that of Polystomella crispa. In her fig. 34 (see Fig. 4) she elegantly pieced together her own life cycle observations with those of Lister to show the key events. Figures $5 \mathrm{a}$ and $\mathrm{b}$ show some of Lister's drawings of juveniles dispersing from the parent. Other species considered are Myxotheca arenilega Føyn, Iridea lucida J. Le Calvez, Patellina corrugata Williamson, Spirillina vivipara Ehrenberg, Discorbis mediterranensis (d'Orbigny), Discorbis orbicularis (Terquem), and Tretomphalus sp. The section is rounded off with a brief description of the classification (essentially that of Cushman, 1948).

The life cycle of Elphidium crispum has come to be regarded as the classic life cycle and Goldstein (1999) has pointed out that it is fortuitous that Schaudinn, Lister and Jepps all chose to work on the same species. It has subsequently been shown that other patterns occur in some foraminiferal species. Also, it was not until the work of Le Calvez, 1946; 1950) that the position of meiosis in the life cycle was established (in Patellina corrugata); it occurs in the agamont (microspheric) as part of multiple fission (Goldstein, 1999).

\section{EARL HAMLET MYERS (1898-1975)}

The American zoologist Earl Hamlet Myers (Fig. 6) made some notable contributions to understanding the life cycle and ecology of benthic foraminifera. Following his PhD at Scripps in 1934 (at the age of 36), he held a Gugenheim Fellowship in 1938-39. He visited The Laboratory of the Marine Biological Association, Plymouth, England, in 1938-40, where much of his work was done on Elphidium crispum. Remarkably, some of the samples were collected by Bill Searles who, as a young man, collected material for Lister in the 1890s (Myers, 1942a). In 1942 Myers visited Woods Hole Oceanographic Institution, USA. He was particularly interested in applying new techniques to the study of microscopic organisms. Myers pioneered the preparation of a new technique for making slides of Amoeba (Myers, 1932), developed a mouth pipette for separating small organisms (Myers, 1934), introduced culture methods for foraminifera (Myers, 1937), and time-lapse photography (Myers, 1935a). For the latter, he had to shoot each individual frame, day and night, as there was no automated time-lapse mechanism. He also developed a paraffin embedding bath to assist sectioning of specimens (Jepps, 1942). In his 1936 paper Myers acknowledges the support of T. Wayland Vaughan for his work. He also mentions the guiding influence of C.A. Kofoid and thanked Arthur Earland for helping him 'to better understand certain phases of the problem' through his published works and personal letters. From comments by Jepps (1942) it is evident that Myers was assisted in his work by his wife and he acknowledges this in his 1942a paper. 

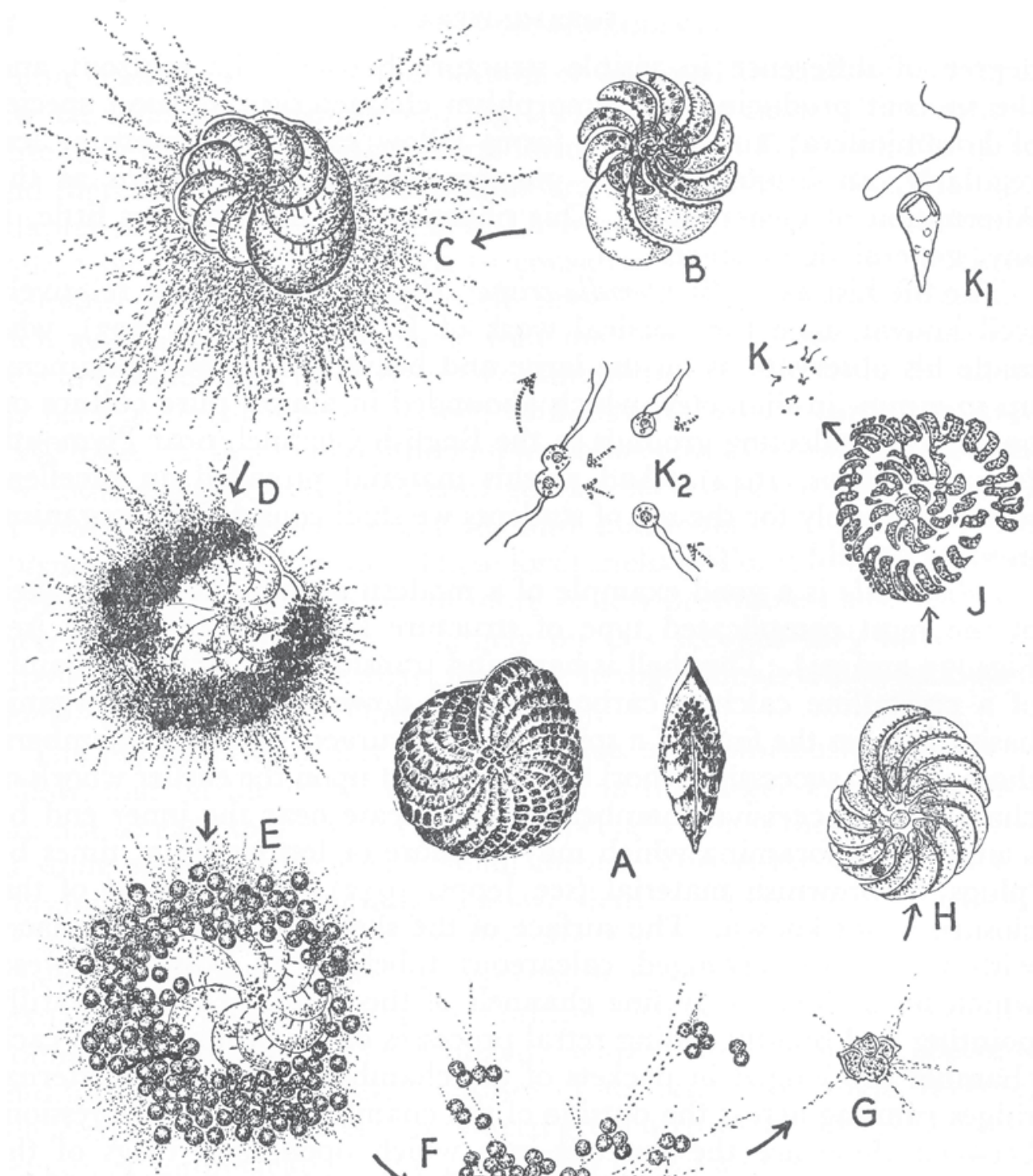

\section{A}

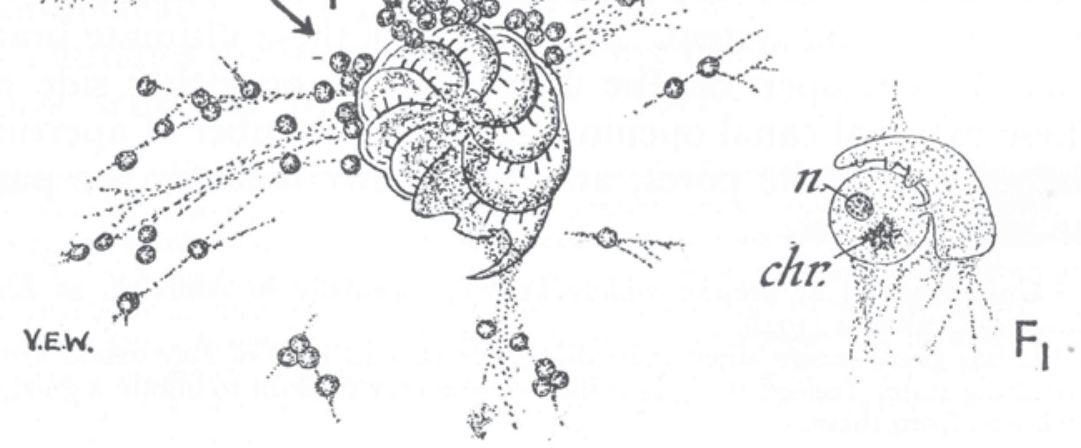

Fig. 4. The life cycle of the foraminiferan Polystomella crispa illustrated by Jepps (1956) with modifications from Lister (1895): (A) test; (B) the stained protoplasm of a whole microspheric individual - the dots are nuclei. (C-F) A live microspheric form recorded by Lister (1903) over a period of 12 hours: (C) pseudopodia form a halo around the brown test; (D) the protoplasm has passed out of the test; (E) cleavage (fission) has led to the formation of $\sim 200$ megalospheric initial chambers; (F) some hours later, dispersal away from the parent test showing damage caused by their emergence; (F1) formation of a second chamber after 1-2 hours (n. nucleus, chr. chromidial shreds, i.e. remains of granules in protoplasm). (G) Young about two days old. (H) Fully grown decalcified megalospheric individual. (J) Section of a megalospheric individual in the following spring when sporulation was taking place (production of gametes). The protoplasm is divided into spherical bodies each with its own nucleus. Finally the whole test is filled with mobile flagellated gametes. (K) The gametes leave the test. (K1) One gamete shown in detail. (K2) Fusion of gametes (figure after Schaudinn, 1903). The zygotes grew into young 5-chambered microspheric individuals before they died (Jepps, 1942). 


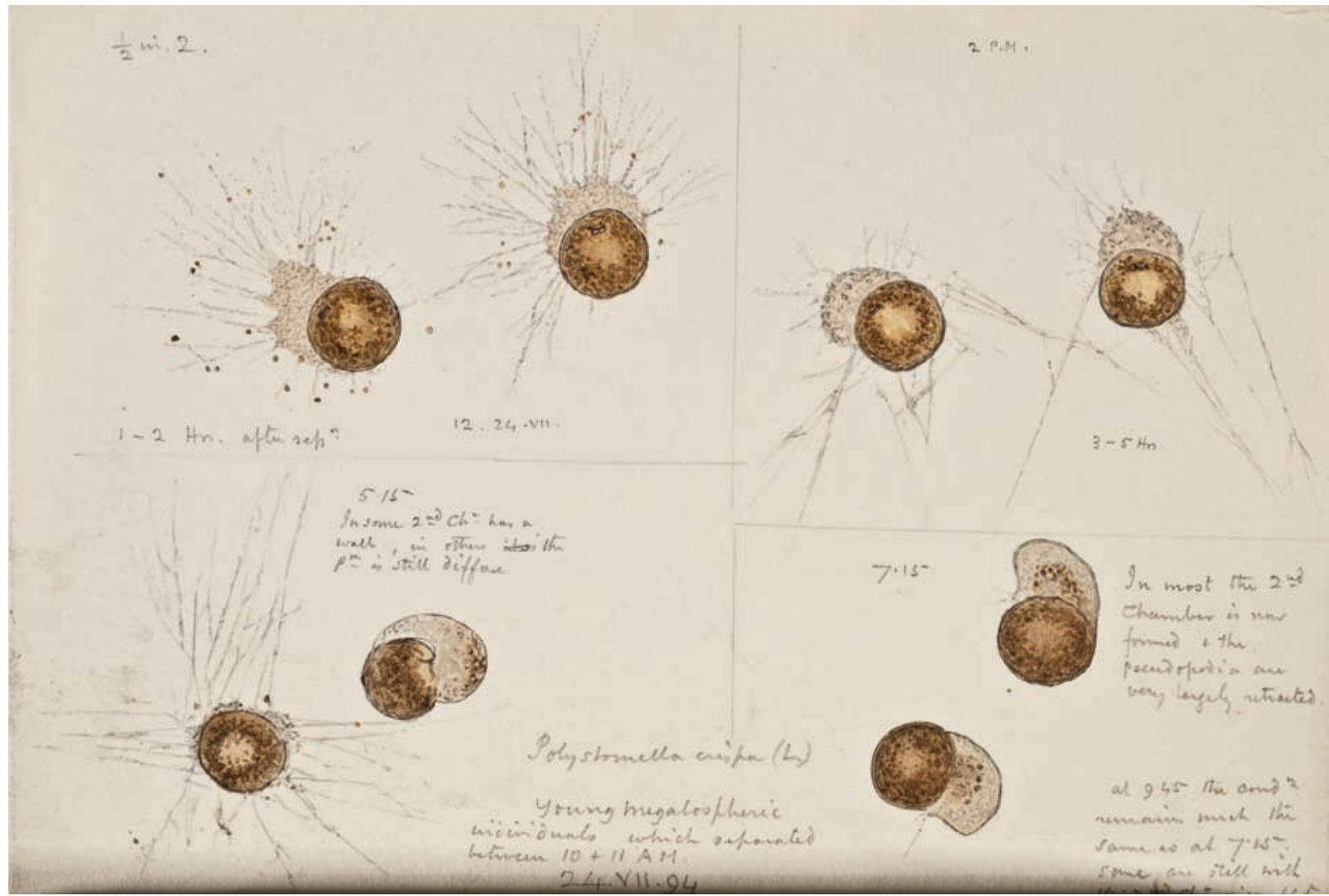

(a)

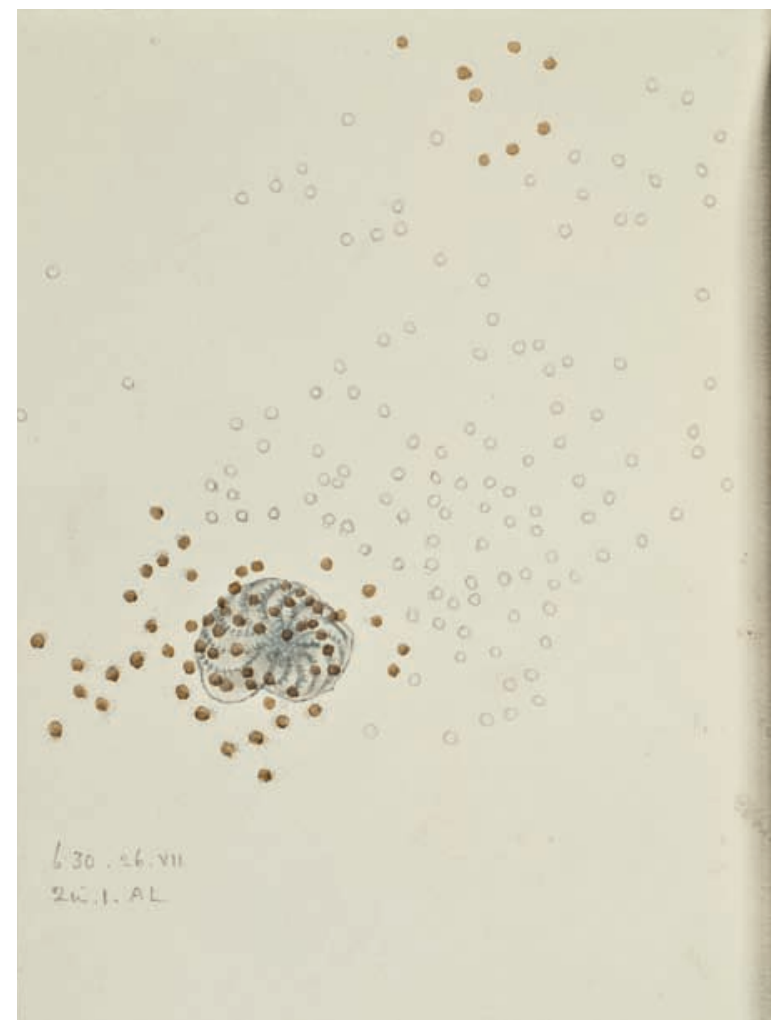

(b)

Fig. 5. (a, b) Lister's drawings of juvenile megalospheric Polystomella crispa with pseudopodia (Lister, Lab. Notebook, vol. 2, pp. 116 and 117 , respectively). 


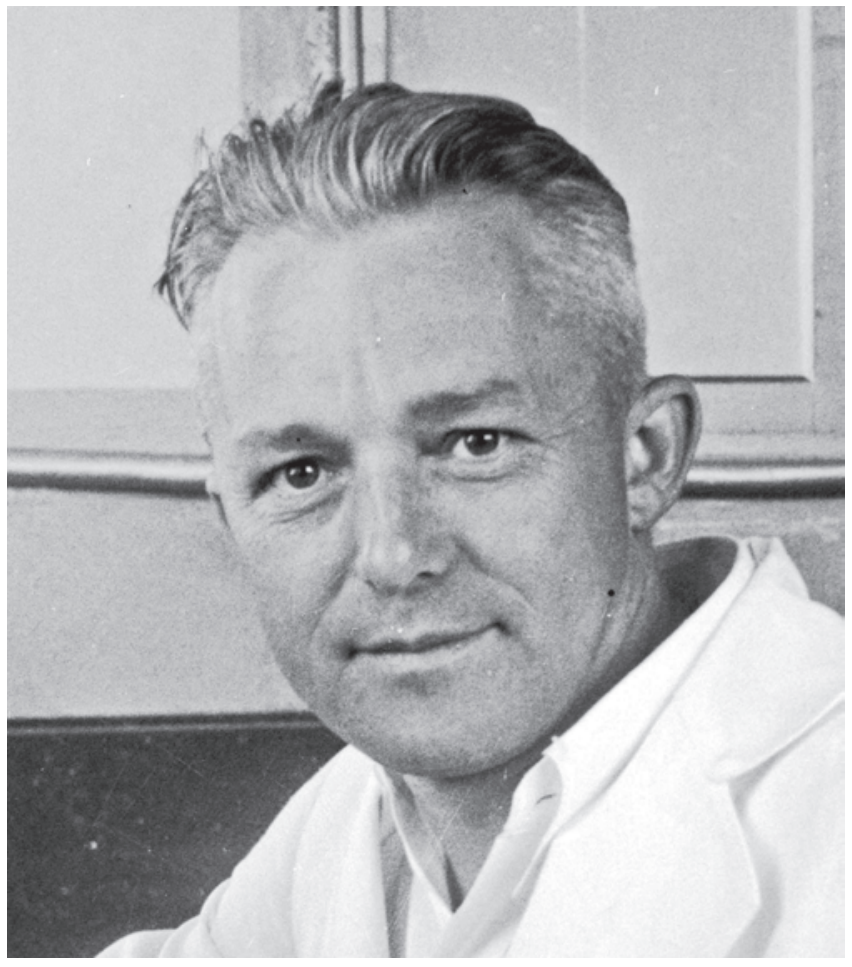

Fig. 6. Earl Myers, 1935 (courtesy of Scripps Institution of Oceanography Archives, UC San Diego Libraries, USA).

Myers' first major contribution was to the life cycle of foraminifera in a programme planned by $\mathrm{T}$. Wayland Vaughan (Myers, 1935a). He noted that the life cycle proposed by Lister (1895) and confirmed by Schaudinn (1903), 'is nowhere supported by adequate cytological evidence, nor has any figure or description of the zoöspore been produced' (Myers, 1935b, p. 403; 'zoöspore' = gamete). Myers' 1935a paper rectified this for Patellina corrugata and he commented that 'Beyond the fact that dimorphism in the foraminifera is caused by an alternation of generations, the reader will find that the life cycle herein described has little in common with the findings of previous workers'. He found no flagellated gametes (zoöspores of Lister) and the haploid gametes were described as 'spherical amoebulae'. Together with C.A. Kofoid and J.E. Gullberg, he made a time-lapse 30-minute film condensing 41 days of reproductive and developmental activity. The duration of the reproductive cycle was established as 9-12 days for the megalospheric gamonts to reach sexual maturity and 18-21 days for the microspheric agamonts to mature and undergo multiple fission. In Spirillina vivipara the cycle was found to be similar (Myers, 1936) and he suggested that the distribution of benthic foraminifera in shallow waters depends on 'a brief pelagic phase assumed by juvenile or adult individuals'. This concept is now termed propagules (see Alve \& Goldstein, 2010, and references therein). He then reviewed the current state of knowledge on the reproductive cycle (Myers, 1938) before moving on to other species. By 1940 Myers had discovered that Discorbis patelliformis (Brady) and other Discorbis species have flagellated gametes thus confirming an observation by Lister (1895) who had regarded them as problematical. Myers noted that normally individual foraminifera avoid one another in cultures but that sometimes two or more megalospheric individuals of D. patelliformis moved together so that their umbilical sides and their apertural faces were juxtaposed (this is termed syzygy; Myers, 1940, pp. 219-20). There is dissolution of umbilical test wall and the multiple tests become cemented together. Syzygy takes place prior to the sexual phase of the life cycle. Fertilization of the gametes takes place in the combined tests of two or more mononucleate megalopsheric gamonts in syzygy. Such fused tests are sometimes mistaken for deformed individuals (Myers 1933). When they break apart after reproduction the individual tests have an excavated cavity instead of an umbilical wall. Myers also contributed to understanding the life cycle of planktonic foraminifera (Myers, 1943).

The second major contribution was to ecology. Myers was at the forefront of foraminiferal ecological research and was the first to consider such matters as the rates of production of individuals and the rates at which tests are added to the sediment (Myers, 1942a, b, c). He investigated the size distribution of living individuals through successive months, drew growth curves for both microspheric and megalospheric generations of Elphidium crispum and considered rates of survivorship. He also attempted correlations with environmental parameters and concluded that the numbers of foraminifera are related to the amount of food in the water and the amount of sedimentary organic matter (Myers, 1942a). Although a zoologist, he was keenly aware of the importance of foraminifera in geological investigations, especially for petroleum. His final foraminiferal work was the contribution on ecology for the landmark publication on ecology and palaeoecology published by the Geological Society of America (Myers \& Cole, 1957).

\section{CONCLUDING REMARKS}

Compared with other protozoa, the two-year life cycle of Polystomella crispa $=$ Elphidium crispum is very long. This led Vickerman to comment:

On learning this, one can see why - despite Heron-Allen's praise for their capacity to withstand neglect - the living foraminifera have attracted relatively few protozoologists, at the same time being inordinately impressed by the patience and perseverance of the few who have been drawn to them (Vickerman \& Sleigh, 2000, p. 77).

\section{ACKNOWLEDGEMENTS}

I thank the University of Southampton for continuing to providing facilities since my retirement in 2003. I am grateful to Clive Jones, Giles Miller, the photographic unit and library staff, all of the Natural History Museum, London, for their help. Michael Sleigh (Southampton) and Maggie Reilly (Glasgow) are thanked for their attempts to resolve the uncertainty over an image of Jepps published in Vickermann \& Sleigh (2000). The Royal Society, London, is thanked for access to their archives. The Scripps Institution of Oceanography Archives, UC San Diego Libraries, USA, are thanked for permission to use the photograph of Myers, and the Natural History Museum, London, for that of Lister. The Natural History Museum retains copyright of Figs 1, 2, 3 and 5. My thanks also go to referee Kate Darling (Edinburgh) for her helpful suggestions. A grant from The Micropalaeontological Society for colour printing is gratefully acknowledged. This paper marks 50 years of publishing by the author. 


\section{Manuscript received 6 December 2011 \\ Manuscript accepted 10 January 2012}

Scientific Editing by Alan Lord.

\section{REFERENCES}

Alve, E. \& Goldstein, S.T. 2010. Dispersal, survival and delayed growth of benthic foraminiferal propagules. Journal of Sea Research, 63: 36-51.

Cushman, J.A. 1948. Foraminifera, their classification and economic use, 4th edn. Cambridge, Massachusetts, USA, 605pp.

Earland, A. \& Jepps, M.W. 1943. Note on an abnormal specimen of Elphidium crispum L. Journal of the Royal Microscopical Society, 63: 43-47.

Ehrenberg, C.G. 1838. Die Infusionsthierchen als volkommene Organismen, vols 1, 2. Leipzig.

Gervais, P. 1847. Sur un point de la Physiologie des Foraminifères. Comptes rendus hebdomadaires de l'Académie des Sciences, 25: 467-468.

Goldstein, S.T. 1999. Foraminifera: a biological overview. In Sen Gupta, B.K. (Ed.), Modern Foraminifera. Kluwer, Dordrecht, The Netherlands, 37-55.

Hemleben, Ch., Spindler, M. \& Anderson, O.R. 1989. Modern Planktonic Foraminifera. Springer-Verlag, New York, 363pp.

Heron-Allen, E. 1930. The further and final researches of Joseph Jackson Lister uponthe reproductive processes of Polystomella crispa (Linné). Smithsonian Miscellaneous Collections, 82(9): 1-11.

Jepps, M.W. 1926. Contribution to the study of Gromia oviformis Duj. Quarterly Journal of Microscopical Science, 70: 701-719.

Jepps, M.W. 1942. Studies on Polystomella Lamarck (Foraminifera). Journal of the Marine Biological Association, 25: 607-666.

Jepps, M.W. 1953. Nuclei of Cycloclypeus carpenteri Brady. Nature, London, 171: 1114-1115.

Jepps, M.W. 1956. The Protozoa, Sarcodina. Oliver and Boyd, Edinburgh, $183 \mathrm{pp}$.

Le Calvez, J. 1938. Recherches sur les Foraminifères. I. Développement et reproduction. Archives de Zoologie Expérimentale et Générale, 80: 163-333.

Le Calvez, J. 1946. Place de la reduction chromatique et alternance de phases nucléaires dans le cycle des foraminifères. Comptes rendus hebdomadaires de l'Académie des Sciences, Paris, 222: 612-614.

Le Calvez, J. 1950. Recherches sur les foraminifères, 2. Place de la méiose et sexualité. Archives de Zoologie Expérimentale et Générale, 87: 211-243.

Lister, J.J. 1892-1909. Laboratory note books. Unpublished. Natural History Museum, London.

Lister, J.J. 1895. Contributions to the life-history of the Foraminifera. Philosophical Transactions of the Royal Society, B186: 401-453.

Lister, J.J. 1903. The Foraminifera. In Lankester, E.R. (Ed.), A Treatise on Zoology, 1(2): 47-149.

Lister, J.J. 1905. On the dimorphism of the English species of Nummulites and the size of the megalosphere in relation to that of the microspheric and megalospheric tests of this genus. Proceedings of the Royal Society, B76: 298-319.

Lister, J.J. 1906. The life-history of the Foraminifera. British Association for the Advancement of Science, Transactions of Section D: 583-596.
Lister, J.J. 1907. The Foraminifera. Proceedings of the Royal Institution of Great Britain, 18: 489-497.

Loeblich, A.R. \& Tappan, H. 1987. Foraminiferal Genera and their Classification. New York: Van Nostrand Reinhold, 1: 970pp; 2: 212pp.

Murray, J.W. 1963. Ecological experiments on Foraminiferida. Journal of the Marine Biological Association, 43: 621-642.

Myers, E.H. 1932. A new technique for making Amoeba slides. Transactions of the American Microscopical Society: 52.

Myers, E.H. 1933. Multiple tests in the foraminifera. Proceedings of the National Academy of Science, 19(10): 893-899.

Myers, E.H. 1934. A mouth pipette and containers for small organisms. Science, 77: 609-610.

Myers, E.H. 1935a. The life history of Patellina corrugata Williamson, a foraminifer. Bulletin of Scripps Institution of Oceanography, Technical Series, 3(15): 355-392.

Myers, E.H. 1935b. Morphogenesis of the test and the biological significance of dimorphism in the foraminifer, Patellina corrugata Williamson. Bulletin of Scripps Institution of Oceanography, Technical Series, 3(16): 393-404.

Myers, E.H. 1936. The life-cycle of Spirillina vivipara Ehrenberg, with notes on morphogenesis, systematics and distribution of the foraminifera. Journal of the Royal Microscopical Society, 56: 120-146.

Myers, E.H. 1937. Culture methods for marine foraminifera of the littoral zone. In Galtsoff, P.S., Lutz, F.E., Welch, P.S. \& Needham, J.G. (Eds), Culture Methods for Invertebrate Animals. Comstock Publishing Co., New York, 93-96.

Myers, E.H. 1938. The present state of our knowledge concerning the life cycle of the foraminifera. Proceedings of the National Academy of Science, 24: 10-17.

Myers, E.H. 1940. Observations on the origin and fate of flagellated gametes in multiple tests of Discorbis (foraminifera). Journal of the Marine Biological Association of the United Kingdom, 24: 201-226.

Myers, E.H. 1942a. A quantitative study of the productivity of the foraminifera in the sea. Proceedings of the American Philosophical Society, 85(4): 325-341.

Myers, E.H. 1942b. Biological evidence as to the rate at which tests of foraminifera are contributed to marine sediments. Journal of Paleontology, 16: 397-398.

Myers, E.H. 1942c. Rate at which foraminifera are contributed to marine sediments. Journal of Sedimentary Petrology, 12: 92-95.

Myers, E.H. 1943. Biology, ecology and morphogenesis of a pelagic Foraminifer. Stanford University Publication, Biology Series, 9: 5-30.

Myers, E.H. \& Cole, W.S. 1957. Foraminifera. In Hedgpeth, J.W. (Ed.), Treatise on Marine Ecology and Paleoecology, Part 1. Geological Society of America, Memoir, 1: 1075-1082.

Schaudinn, F. 1903. Untersuchungen über die Fortpflanzung einiger Rhizopoden. I. Polystomella crispa. In 1911, Fritz Schauddinns Arbeiten. Verlag Leopold Voss, Hamburg and Leipzig, 499-501.

Vickerman, K. \& Sleigh, M. 2000. A Century of Protozoology in Britain. The British Section of the Society of Protozoologists, 198pp.

Williamson, W.C. 1851. On the minute structure of the calcareous shells of some recent species of foraminifera. Transactions of the Microscopical Society, 3: 105-128. 


\section{New developments for 2012}

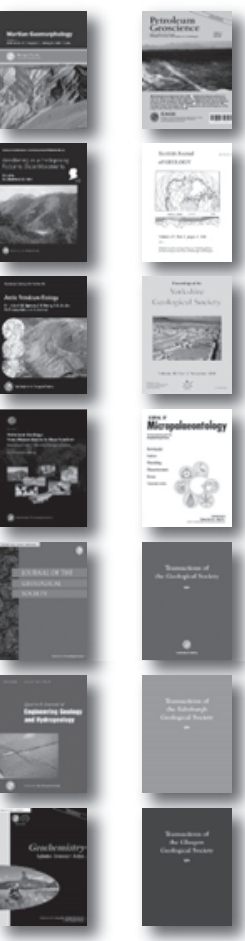

\section{What is the Lyell Collection?}

Launched in 2007 the Lyell Collection is an online collection comprising the Society's journal titles, Special Publications and key book series. Cutting edge science sits alongside important historical material, all captured and presented to the highest electronic standards and benefiting from the extensive functionality of HighWire Press' H2O platform.

With 240000 peer-reviewed pages, 25000 articles and 1000 volumes, the Lyell Collection is an invaluable tool for the researcher and student alike.

- Full text in HTML and PDF format

- Actively linking to cited references

- Free public access to alerts, search functions and abstracts

- Selected open access articles

- Hosted by Highwire Press

\section{The Geological Society}

The Geological Society of London was founded in 1807 and is the UK national society for geosciences, with over 10000 members. It is a global leader in Earth science publishing, dedicated to providing a high-quality service throughout the world.

\section{GEGFACETS.}

The Society is collaborating with Elsevier to launch a Lyell Collection module on Geofacets. Selected titles will be available on Geofacet's searchable database of georeferenced geological maps that enables geoscientists working in the early stages of upstream exploration to assess a region's or basin's geological characteristics.

- Intuitive search features designed for geoscientists

- Map overlays

- Access to thousands of georeferenced maps

- Links to associated articles

- For further information please contact sales@geolsoc.org.uk

\section{Special Publication archives}

Online archives of the first 300 volumes of the Geological Society's Special Publications are now available for sale on a one-off, perpetual access basis. Prices include a 10\% discount for those purchasing the full archive (volumes 1-300)

\section{New titles}

Two new archival titles will be launched and made available to Lyell Collection Complete subscribers at no additional charge.

- Transactions of the Edinburgh society

- Transactions of the Glasgow society

\section{Lyell Collection for libraries 2012: content and prices}

\begin{tabular}{|c|c|c|c|c|c|}
\hline TITLE & 2012 Content & Access options & UK price $f^{*}$ & RoW price $f^{*}$ & RoW price US\$* \\
\hline Lyell Collection Complete & All content & $\begin{array}{l}\text { Online } \\
\text { Online }+ \text { Print } \\
\text { Online }+ \text { Special Publications Print** }\end{array}$ & $\begin{array}{l}f 3,661 \\
f 4,119 \\
f 3,911\end{array}$ & $\begin{array}{l}f 3,889 \\
f 4,375 \\
f 4,139\end{array}$ & $\begin{array}{l}\$ 7,778 \\
\$ 8,750 \\
\$ 8,278\end{array}$ \\
\hline Special Publications & $360+$ volumes & $\begin{array}{l}\text { Online } \\
\text { Online + Print }\end{array}$ & $\begin{array}{l}f 2,158 \\
f 2,427\end{array}$ & $\begin{array}{l}f 2,250 \\
f 2,531\end{array}$ & $\begin{array}{l}\$ 4,499 \\
\$ 5,061\end{array}$ \\
\hline Engineering Geology Special Publications & $25+$ volumes & Available as part of Lyell Collection Complete only & & & \\
\hline Memoirs & $36+$ volumes & Available as part of Lyell Collection Complete only & & & \\
\hline Petroleum Geology Conference Series & 4 volumes & Available as part of Lyell Collection Complete only & & & \\
\hline Journal of the Geological Society & 1845 to current & $\begin{array}{l}\text { Online } \\
\text { Online + Print }\end{array}$ & $\begin{array}{l}f 842 \\
f 948\end{array}$ & $\begin{array}{r}\mathbf{f} 935 \\
\mathbf{f 1}, 052\end{array}$ & $\begin{array}{l}\$ 1,871 \\
\$ 2,105\end{array}$ \\
\hline Quarterly Journal of Engineering Geology and Hydrogeology & 1967 to current & $\begin{array}{l}\text { Online } \\
\text { Online + Print }\end{array}$ & $\begin{array}{l}\text { f399 } \\
\text { f449 }\end{array}$ & $\begin{array}{l}\text { f447 } \\
\text { f502 }\end{array}$ & $\begin{array}{c}\$ 893 \\
\$ 1,005\end{array}$ \\
\hline Geochemistry: Exploration, Environment, Analysis & 2001 to current & $\begin{array}{l}\text { Online } \\
\text { Online + Print }\end{array}$ & $\begin{array}{l}f 215 \\
\text { f242 }\end{array}$ & $\begin{array}{l}f 243 \\
f 274\end{array}$ & $\begin{array}{l}\$ 487 \\
\$ 548\end{array}$ \\
\hline Petroleum Geoscience & 1995 to current & $\begin{array}{l}\text { Online } \\
\text { Online + Print }\end{array}$ & $\begin{array}{l}\text { f361 } \\
\text { f406 }\end{array}$ & $\begin{array}{l}\mathrm{f} 361 \\
\mathrm{f} 406\end{array}$ & $\begin{array}{l}\$ 722 \\
\$ 813\end{array}$ \\
\hline Scottish Journal of Geology & 1965 to current & $\begin{array}{l}\text { Online } \\
\text { Online + Print }\end{array}$ & $\begin{array}{l}f 200 \\
f 225\end{array}$ & $\begin{array}{l}f 200 \\
f 225\end{array}$ & $\begin{array}{l}\$ 400 \\
\$ 450\end{array}$ \\
\hline Proceedings of the Yorkshire Geological Society & 1837 to current & $\begin{array}{l}\text { Online } \\
\text { Online + Print }\end{array}$ & $\begin{array}{l}f 162 \\
f 183\end{array}$ & $\begin{array}{l}\text { f162 } \\
\text { f183 }\end{array}$ & $\begin{array}{l}\$ 324 \\
\$ 365\end{array}$ \\
\hline Journal of Micropalaeontology & 1991 to current & $\begin{array}{l}\text { Online } \\
\text { Online + Print }\end{array}$ & $\begin{array}{l}\text { f184 } \\
\text { f207 }\end{array}$ & $\begin{array}{l}\text { f184 } \\
\text { f207 }\end{array}$ & $\begin{array}{l}\$ 368 \\
\$ 413\end{array}$ \\
\hline Transactions of the Geological Society & 1811 to 1856 & Available as part of Lyell Collection Complete only & & & \\
\hline Transactions of the Edinburgh Geological Society & 1870 to 1963 & Available as part of Lyell Collection Complete only & & & \\
\hline Transactions of the Glasgow Geological Society & 1863 to 1965 & Available as part of Lyell Collection Complete only & & & \\
\hline Special Publications Archive & & & & & \\
\hline $\begin{array}{l}\text { Archive } 1 \\
\text { Archive } 2 \\
\text { Archive } 3 \\
\text { Archive } 1 \text { - } 3\end{array}$ & $\begin{array}{l}\text { Volumes } 1-100 \\
\text { Volumes } 101-200 \\
\text { Volumes } 201-300 \\
\text { Volumes } 1-300\end{array}$ & $\begin{array}{l}\text { Online } \\
\text { Online } \\
\text { Online } \\
\text { Online }\end{array}$ & $\begin{array}{l}f 2,500 \\
f 2,500 \\
f 2,500 \\
f 6,750\end{array}$ & $\begin{array}{l}f 2,500 \\
f 2,500 \\
f 2,500 \\
f 6,750\end{array}$ & $\begin{array}{c}\$ 5000 \\
\$ 5000 \\
\$ 5000 \\
\$ 13,500\end{array}$ \\
\hline
\end{tabular}

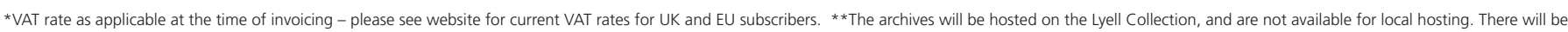
no ongoing maintenance or access charge. Prices are for single sites only. Please apply for multi-site and consortial pricing.

To order the Lyell Collection or individual journal titles, or request further information or a free trial, please contact:

In UK and Europe: Email: geologicalsociety@accucoms.com Telephone: +31 715247630 In Korea: Email: :jkim1@ebsco.com Telephone: 82-2-598-2571 (ext. 230)

In Australian and New Zealand: Email: dviollet@ebsco.com Telephone: $+6175453-7675$ In South America: Email: info@dotlib.com Telephone: +55 (21) 3431-3430
In USA and Canada: Email: geologicalsociety@pcgplus.com Telephone: +1 6173954065 In Japan: Email. kobayashi@ebsco.co.jp Telephone: +81 (0)3 53275273

In Taiwan, Hong Kong, Macau, SE Asia: Email: salestw@ebsco.com Telephone: +886 287860601 All other regions: Email: sales@geolsoc.org.uk Telephone: +44 (0)1225 445046 